\title{
Claiming Queer Territory in the Study of Subcultures and Popular Music
}

\author{
By Jodie Taylor, Griffith University \\ Published in Sociology Compass 7(3) 2013.
}

\begin{abstract}
For both the heterosexual and queer subject, subcultural participation and stylistic modes of cultural production and consumption, including popular music, are critical mechanisms aiding in the construction and expression of identity. Yet, in spite of abundant empirical examples of queer music cultures, subcultural studies scholars have paid minimal attention to queer sexualities and their concomitant stylistic modalities. In this article, I claim the importance of queer subterranean music cultures by synthesising significant literatures from various fields of inquiry including cultural sociology, popular musicology and queer studies. To begin, I will briefly clarify to whom and about what queer (theory) speaks. I then go on to offer an overview of subcultural and popular music research paying particular attention to the subaltern queer subject and surveying queer criticism within each field. Accordingly, I discuss various sites of popular music production and subcultural style such as punk and hip-hop, to show how non-heterosexual subjects carve space for resistant queer sexualities and merge queer sensibilities with pre-existing cultural forms. This article consolidates interdisciplinary approaches that will benefit scholars invested in the study of queer subcultures and popular music.
\end{abstract}

\section{Introduction}

Formed on the basis of shared experiences, tastes and values, queer counterpublic networks and oppositional communities can give rise to complex multi-layered local and translocal queer music scenes and subcultures. Queer subcultures become generative spaces where queer feelings, identities, experiences and politics are frequently expressed and negotiated in aesthetic terms: that is, through style. Accordingly, popular music, which encompasses music-making, performance and/or consumption, is a meaningful agent of queer style. Queerness pervades and borrows from multiple sites of subcultural production and queer scenes coalesce around a diverse range popular music styles including rock, punk, metal, hip-hop, electronic dance music (EDM) and pop.

'Queer' is a complex and often contested term that can describe multiple identities, social relations, sensibilities, politics and fields of study. To begin, then, it is useful to define and situate some terms and applications. Queer can describe many gender and sexual identities and lifestyle practices including, for example, lesbian, gay, bisexual, pansexual, asexual, butch, femme, androgyne, genderqueer, intersex, transgender, polyamory, non-monogamy, practices of bondage, discipline, sadism or masochism (BDSM) and other radical gender and/or sexual practitioners. Taking up a postmodern and poststructuralist critique of identity, queer poses a challenge to essentialist notions of a fixed, coherent and universal subjectivity (e.g. see de Lauretis 1991; Doty 1993; Giffney 2009; Halperin 1995; Jagose 1996; Meyer 1994; Phelan 1997; Sedgwick 1993; Sullivan 2003; Warner 1993, 1999). As a kind of identity, or what Muñoz (1999) calls a mode of 
'disidentification', queer becomes a resistant identity, in that it resists normalising and privileging certain identity criteria and enforcing ridged identity categories. Thus, queer is not a concrete or bounded category, nor does it function solely as a substitute or catchall term for lesbian and gay.

Queer theory supposes that identities are not normal or natural; instead they are performative and discursively constituted (Butler 1988, 1990, 1993; Foucault 1979, [1976]). In other words, we come to understand identity as stable only through the repetition of stylised acts, such as the association of femininity with female bodies, nurturing and certain styles of dress and personal grooming. The only reason that femininity (or any other expression of identity) appears 'natural' to the category of woman is because it has been repeated by with such frequency. The more these acts and identities are repeated, the more 'natural' or 'normal' they appear. It follows that those people who most successfully measure up to what society deems 'natural' or 'normal' acquire the most power and privilege, like, for example, property rights or the right to marry.

In contrast to gender-centric investigations typified by much of the feminist scholarship that preceded it, Case notes that 'queer works not at the site of gender but at the site of ontology to shift the ground of being itself ... [to] attack the dominant notion of the natural' (cited in Hall 2003, 55). Queer theory is meant to agitate, subvert and disrupt notions of the natural, normative and the canonical, problematising historical meta-narratives, deconstructing social privilege, hierarchies and power relations. It resists the logic of heterosexual hegemony: that is, the idea that our biological sex should determine the way we express our gender and our sexual desires (see Butler 1993). It deconstructs heteronormative power relations: that is, the cultural bias towards opposite sex attraction and the social privileges afforded to heterosexuality (see Berlant and Warner 1998; Corber and Valocchi 2003). Furthermore, it critiques the rise of homonormativity, which describes the neoliberal sexual politics of assimilated lesbian and gay minorities (see Duggan 2003).

Sexuality plays a critical role in everyday forms of cultural expression, public and political life. The cultural vocabularies of queer activism and the artistic expressions of queer feeling are multiple and sophisticated, however queer political identities do not always present in the form of immediately recognisable organisations, institutions or coherent cultural groups. On this point, Cvetkovich argues that 'queer theory contributes to the more expansive definition of political life' and fosters a broader understanding of the ways sexuality manifests as a range of political identities that 'are implicit within structures of feeling, sensibilities, everyday forms of cultural expression and affiliation' $(2007,463)$.

Over the last three decades, 'queering' has become a widely accepted hermeneutic in many fields of cultural, philosophical and social inquiry. As a way of countering hegemonic textual readings and cultural authority, queering offers a critique of what Warner (1999) calls 'regimes of the normal'. Accordingly, studies of queer identities, queer subcultures and queer popular music production and consumption are not native to any single discipline. Rather, given the complexities of understanding how various types of popular music subcultures function as everyday sites of self-making and collective identification for queer people, coupled with the various ways queer meanings can be inscribed in the discourses of popular music, such studies are inherently interdisciplinarity. With the advent of queer theory and, in recent years, the burgeoning field of multidisciplinary queer studies, it is common for scholars to approach the study of queer subcultures and popular musics from one discipline (e.g. cultural studies, sociology, musicology, anthropology,) but necessitates the incorporation of knowledge from other fields. 
While this article advocates queer thinking, before proceeding, it is useful to acknowledge that the anti-identity politics of queer and multidisciplinarity of queer studies is not without contest. Commonly criticised as US-Anglo-centric, many question the broader feasibility of queer studies, advocating a perspectival shift is needed when looking beyond Western cultural contexts (e.g. Boellstorff 2007; Martin et al. 2008). Others contend that by destabilising the subject and undermining mainstream sexual rights discourse, queer debases collective political action and does little to bring about effective social change (e.g. Edwards 1998; Weeks 2000; J. Taylor 2010; Y. Taylor 2010). Moreover, queer is sometimes said to privilege white gay masculinities and as thus been accused of denying the lived reality of women, lesbians and trans people (e.g. Jeffreys 2003; Richardson et al. 2006; Stryker 2006). Finally, others still have questioned the empirical value of queer scholarship, suggesting that it offers little in the way of thinking about identity beyond textual analysis (e.g. Escoffier 1990; Plummer 1998). Such criticisms do not mean that queer should be done away with; rather, they should be taken as points to keep front-ofmind so as to remedy problematic aspects, or at the very least, avoid compounding them.

In this article, I claim the importance of queer subterranean music cultures by critically consolidating relative work from cultural sociology, popular musicology and queer studies. Furthermore, underscoring how queer subterranean music cultures may advocate a revision of aspects of current subcultural frameworks. My intention is not to produce a discrete account of a particular queer subculture or queer popular music form. Rather, this article offers a heuristic approach to understanding the intersecting spheres of queer, subcultural and popular music discourses and why, as Halberstam has suggested, queer subcultures 'need to be reckoned with on [their] own terms' $(2005,154)$. To do this, I begin by situating relevant theoretical concepts and polemics within each field, paying particular attention to the subaltern queer subject and the scholarship that has most effectively accounted for queer socio-musical relations. I then proceed with an illustrative discussion of select queer popular music scenes which, covering a range of stylistic forms, underscore queer logics of subcultural style and highlight characteristics of queer subcultural formations.

\section{Subcultures, popular music and queer sexualities}

With an emphasis on juvenile delinquency, criminal gangs, social deviance and urbanisation, the study of subcultures began in the 1920s at the University of Chicago (e.g. Cressy 1932; Whyte 1943). Then, some 50 years on, following the rise of post-war counterculture in the UK and US, social scientists and humanities scholars at Birmingham Centre for Contemporary Cultural Studies (CCCS) redeveloped theories of subcultural formation through their analysis of working-class style-based youth cultures of postWorld War II Britain, such as teddy boys, mods, rockers, skinheads, bikers, hippies and punks (e.g. Hall and Jefferson 1976; Hebdige 1991 [1979]). Taking a neo-Marxist approach to class and power, subcultures were theorised by the CCCS as symbolic and aestheticised sites of stylised resistance to Britain's socio-economic and political post-war structures. According to the CCCS model, subversive activities of subcultural stylisation, commonly demonstrated via distinctive ritual practices, argot, music taste and fashion sense (Cohen 1972), functioned as a way for young people to exercise their aversion to bourgeoisie cultural authority and differentiate themselves from their parents' workingclass culture. Engaging in what Hebdige (1991 [1979]) called semiotic guerrilla warfare and Clarke (1976) explains as subcultural bricolage, disenfranchised youth opposed the mainstream sensibilities of dominant culture, which they branded 'straight' or 'square'. In its 
place, they configured new - 'authentic' - minority cultural identities and symbolic forms of meaning by appropriating, reorganising and recontextualising a range of stylistic artefacts.

One of the most crucial stylistic artefacts of subcultural practice is popular music: 'a particularly potent aspect of meaning-making among young people' (Williams 2007, 579). Sociologists commonly understand popular music production and consumption as a vital resource in self-making (DeNora 2000) and, as numerous subcultural studies scholars have shown, popular music is an integral node in the lifeworlds, collective identification and resistance practices of young people (e.g. Becker 1963; Bennett 2000; Frith 1987; Frith and McRobbie 1990, [1978]; Laing 1985; Laughey 2006; Willis 1978). The Birmingham School's class-based analysis of subcultures as substantive and authentic sites of youth cultural resistance persisted for quite some time as the primary theoretical framework for understanding the relationship between popular music, social action, collective identity and belonging. However, the CCCS's ground-breaking sociological work on youth subcultures and popular music have since been criticised for a variety of reasons: not least of which being an overt fascination with the music-related leisure practices of youthful urban white working-class heterosexual males. The centrality of this subject position has since been contested. Consequently, many scholars have attempted to expand subcultural investigations to account for non-white participants and ethnic minorities (e.g. Huq 2006; Valdivia 2003), women and girls (e.g. McRobbie 1994; Driver 2007), locally specific structures of meaning (e.g Bennett 2000; Cohen 1991; Shank 1994) and class mobility (e.g. Chambers 1985; Clarke 1997, [1981]). Recently, the category of youth, which has been the most constant characteristic of subculturalists to date, has also been contested. Across a range of popular music cultures such as punk (Bennett 2006), goth (Hodkinson 2011), northern soul (Smith 2009) and queer club scenes (Taylor 2010a,b), ethnographic studies of ageing subculturalists are revealing that many post-youth subjects find ways to incorporate traditionally youthful activities into their ageing lifestyles while others continue to invest heavily in subcultural practices well beyond their youth (see also Bennett and Hodkinson 2012; Holland 2004).

Since the 1990s, subcultural analysis has taken a distinctly postmodern turn, which, among other things, has demonstrated that subcultures can no longer be figured as homologous formations. Not least, as a kind of grouping refracted through the lens of a working-class parent culture. Rather, in line with a late-modern understanding of the self as a more reflexive, self-conscious process - where biographical narratives a more easily (re)made and (re)constructed (Giddens 1991) - the boundaries of subcultural formations are likewise understood to be reflexive constructs that draw on and symbolically transform a much greater array of available images, objects, texts and musical forms than ever before. Accordingly, alternative analytical framings and theoretical debates have been exhaustingly played out across a variety of cultural forms and contexts and in a range of scholarly volumes. Examples of post-subcultural scholarship, which focus on analytical alternatives to subculture, such as club culture, neo-tribe and scene, can be found in the following: Club Cultures (Thornton 1995), The Clubcultures Reader (Redhead et al. 1997), The Post-subcultures Reader (Muggleton and Weinzierl 2003), After Subculture (Bennett and Kahn-Harris 2004), Music Scenes (Bennett and Peterson 2004) and Youth Cultures: Scenes, Subcultures and Tribes (Hodkinson and Deicke 2007).

It is not my intention here to adjudicate these epistemological distinctions or to compare the usefulness of various updated subcultural critiques and post-subcultural neologisms as this work has been done elsewhere. ${ }^{1}$ Instead, I wish to draw attention to the unique characteristics of queer subcultures, which have been frequently overlooked by 
both subcultural and post-subcultural scholars. Firstly, I will review an important critique of subculture put forward by queer studies scholar Judith Halberstam. Then, drawing on some exemplary cultural and sociological studies of queer subterranean music cultures, I discuss specific subcultural sites of queer popular music production and consumption. This is valuable work, not least in relation to promoting inclusive sociological discussions, but also because an understanding of queer subcultural organisations makes a significant contribution to expanding the critical currency of subcultural studies and furthering subcultural and post-subcultural debates. Moreover, in a contemporary Western social context, I argue that this work is necessary in order for subculture to have continuing value as a social category.

\section{Distinguishing queer subcultures}

All too commonly, the queer subculturalist's voice and their cultural products have been subsumed into heterosexual narratives of stylistic resistance and 'hipness'. Take, for example, the black and Latino gay men and trans people who participated in the Harlem drag balls and house culture from where the dance style of vogueing originated. We see here, in particularly shocking terms that queer racial minority subcultures are at increased risk of erasure than their white heterosexual counterparts. While this may not be malicious, they are made more vulnerable to exploitation, largely due to inequitable dealings between marginalised queer subjects of colour and those people (heterosexed and/or white) who are afforded greater social privilege and power. The latter, for example, includes Madonna with her hit song and music video "Vogue" (1990), and independent filmmaker Jennie Livingston who won accolades for her ethnographic documentary Paris is Burning (1990), which examined the balls, houses and 80s vogueing phenomenon in New York. According to Becquer and Gatti (1997 [1991]), both of these texts 'fetishize an objectified other and/or subsume her under a myth of equality' (452). In both cases, Madonna and Livingston have profited from their respective rearticulation and reinterpretation of vogueing. Both, argue Becquer and Gatti 'participate in production of newness, a process which purports to keep us up-to-date as it continually adds on novelties to a relational system that absorbs them; both contain vogueing beneath the pluralist umbrella of hipness' (452).

Other examples of queer erasure can be found in records of the girl punk movement riot grrrl. As a number of scholars have since argued, although riot grrrl was an important site of subcultural production and consumption for many queer women who sought a 'a refuge from a homophobic punk scene and a conformist gay culture' (Phoenix 1994, 40), queer riot grrrl subjectivities have been frequently overlooked and excluded from official accounts (see Kearney 1997). More recently, and against popular interpretation, Peters has similarly explored the practices of gay emo boys, suggesting that the post-punk youth subculture of emo 'has morphed into a queer entity' (2010, 130).

In the final chapter of her book In a Queer Time and Place: Transgender Bodies and Subcultural Lives (2005), Halberstam attacks the Birmingham School's approach to subcultural analysis for neglecting to examine queer subcultural participants as well as those subcultures that form on the basis of sexuality and articulate a distinctly queer mode of stylistic resistance. While the logics of queer subcultural formations are contextually varied, they tend to generate, absorb and re-channel a much greater variety of styles. Like other subcultural formations, queers use style as a resource for social critique and resistance, but tend to 'oppose not only the hegemony of dominant culture but also the mainstreaming of lesbian and gay culture' (Halberstam 2005, 161). 
Drawing on earlier exemplars of queer subcultural investigations in her critique (e.g. Cvetkovich 2003; du Plessis and Chapman 1997), Halberstam doesn't do away with the term 'subculture'. Rather, citing, by way of example, a variety of queer subterranean popular music forms such as queercore and riot dyke punk rock/pop, queer performance styles such as lesbian slam poetry and drag kinging, and queer counterpublic sex cultures, Halberstam offers four points that must be considered in order to claim queer territory and establish queer visibility in contemporary subcultural studies: (i) queer subcultures blur traditional distinctions between those who study and archive culture and those who make and consume culture, further radicalising recent ethnographic tendencies towards 'insider' research; ${ }^{2}$ (ii) by way of countering the dominant subcultural narrative, which has historically privileged analysis of the leisure pursuits of young white hetero-males, queer subcultural studies should pay particular attention to lesbians, people of colour and other marginalised subcultural producers; (iii) records of queer subcultural production zines, event flyers, online forums and blogs, memoirs, independently distributed recordings, auto-documentaries and the like - are largely ephemeral, thus queer scholars, artists and activists need to develop queer archives in dialogue with one another to enable future engagement with less-commercial sites of queer subcultural production and consumption; (iv) queer subcultures are not always youth-centric as subculturalists often remain active participants well into middle-age. Thus, a queer subcultural analysis must engage a queer critique of (hetero)normative temporalities and intergenerational relations, disrupting both the oedipal logic of youth's rebellious rejection of a monolithic parent culture as well as conventional narratives of youth and ageing.

Bridging cultural sociology and queer theory, Halberstam's critique has set the tone for a new and more effective kind of queer subcultural studies. Since first published in 2003, numerous reprints of Halberstam's argument has appeared in edited volumes, ${ }^{3}$ and select queer scholars have taken up this approach, applying it to a variety of styles and scenes in both explicit and implicit terms. In Driver's empirical study of Queer Girls and Popular Culture (2007) she notes that 'queer girls talk avidly about being part of musical scenes, of becoming transformed in their social lives about the musical world they inhabit' (196). A queer map of these worlds may not conform to standard genre conventions, like, for example, the old worlds of lesbian feminist folk or Womyn's music. While these old world-orders are regularly referenced by queer girl subcultures (Driver 2007; Halberstam 2005; Wilson 2008), contemporary queer girl subcultures extract meaning from multiple sites of popular music, blurring categories of stylistic distinction. According to Driver, in contrast to subcultures conventionally defined, what distinguishes queer girl subcultural practices and descriptions is not a fixity or coherence in terms of identification, taste and patterns of consumption, but 'a mobility and heterogeneity that constitutes group affiliations and self transformations' (215).

Underscoring the translocal spatiality of queer popular music production and consumption, in Taylor's insider ethnographies of multi-gendered queer popular music scenes, she similarly identifies aesthetic heterogeneity, referring to the musical structures of queer self-making and collective action as 'stylistically excessive' Taylor (2010a,b). Patterns of excess, she suggests, relate to the subterranean world-making attempts of many local queer scenes whose members borrow, manipulate and queerly reconstitute a variety of translocal popular music forms including punk, pop, rock, folk, funk and EDM among others. In part, these excessive annunciations problematise conventional logics of what Thornton (1995) has named 'subcultural capital'. As Taylor argues (2012b), in certain contexts, queer uses of music and style can mark distinction, affiliation and communal identification in radically different ways to many hetero, lesbian and gay subcultures. 
Where the latter tend to privilege a delimited and hierarchically organised series of tastes and styles of self-presentation, a queer preview, although not untroubled by its own hierarchies of taste, tends to favour a more excessive array of signifiers. ${ }^{4}$ In other work, Taylor $(2010 \mathrm{a}, \mathrm{b})$ also challenges the youth-centricity and concomitant heteronormative temporality of subcultural studies, expanding Halberstam's claims of intergenerational participation, by examining a local queer music scene in relation to theories of queer time.

Queer subcultural styles which suggest a more bounded relationship with a genre of expression, like, for example, homo-hop (Wilson 2007), dykecore (Halberstam 2005; Shoemaker 2010; Wiedlack 2011; Wilson 2008) and queercore punk (Ciminelli and Knox 2005; Cooper 1996; DeChaine 1997; du Plessis and Chapman 1997; Fenster 1993; Fuchs 1998; Smith 1995; Spencer 2005), further exemplify uniquely queer modalities of stylistic resistance, subcultural identification and musicalised social action. As a brief but noteworthy aside, the studies cited here further punctuate Halberstam's argument regarding the need to pay greater attention to lesbians and people of colour. While this is not an exhaustive survey, it remains evident that scholarship on queer subcultures to date has privileged investigations into certain subcultural forms of queerness, namely the white men of queercore, over those forms linked more directly to women or people of colour.

Queer subcultures cannot be framed as mere spin-offs of hip-hop or punk, nor are they trivial taste cultures allied with the neoliberal (white, middle-class) agenda of mainstream lesbian and gay social movements. Rather, they manifest as assemblies of reconstituted cultural forms and dissident political identities that bespeak the multiple fronts of queer resistance. In his study of homo-hop rap crew Deep Dickollective, Wilson (2007) argues that homo-hop artists are shifting the political grounds of hip-hop from a 'unilateral or monolithic politics, narrowly focused on racial identity' to 'a politics, through hip-hop music and art, that builds political consciousness from a diversity of identities, particularly based on race, sexuality, and class (119). Thus, homo-hop progresses a musiccentered activism and queer critique that unmasks the whiteness and class privilege operating within LGBTQ communities and challenges dominant accounts of hip-hop as a culture frequently characterised by violence, homophobia and misogyny.

Emerging in North America during the mid-1980s and employing the aesthetics of punk rock, queercore and, in its explicitly feminist incarnation, dykecore, also exercise a radical queer social critique that situated itself against what subculturalists originally saw as 'the selfish, over-educated, self-appointed rich people overseeing a vast fake-democratic lesbian and gay multi-national bureaucracy that dictates how we think, dress, act and fuck' (BIMBOX cited in du Plessis and Chapman 1997, 49). Both queercore and dykecore set out to create a queer countercultural sphere constituted via networks of bands, performers, fans, activists, film-makers, zine-makers, writers and clubs that drew on punk's do-it-yourself ethos and a range of other popular music forms. Music, as du Plessis and Chapman (1997) have argued, 'constitutes a code in which denizens of the subcultural world trade signs that have now been transmuted into heretical tokens of recognition' (50). In their revolutionary struggle for distinction (Bourdieu 1993), queercore participants took issue with the homonormative politics of an overly white and middleclass lesbian and gay mainstream as well as with the exclusionary power politics prevalent within hardcore punk. Dykecore has been particularly successful at transforming explicitly macho (and misogynistic) genres such as punk rock into a site of female agency and the 'young women involved in dykecore subculture are vital examples of [a] resurgence of feminist engagement' (Wilson 2008, 65). Today, multi-genre queer music, arts and activist festivals such as Homo A Go $\mathrm{Go}^{5}$ and Queeruption ${ }^{6}$ persist as examples of transformative countercultural action and the queercore legacy. 


\section{Popular musicology and queer sexualities}

While studies of popular music and identity emerged in sociological institutions, they are not confined to this discipline or the field of subcultural studies. In this paper's introduction, I underscored the inherent interdisciplinarity of this undertaking, and so I now turn to popular musicology, discussing how queer socio-musical relations and the study of such relations have transpired within this discipline, highlighting the specific insights it has to offer.

Emerging in the early 1980s with close proximity to lesbian, gay and feminist criticism within traditional/historical musicology (e.g. Brett et al. 1994; McClary 1991), popular musicology exercises a similar concern with the social significance of music: that is, what popular music is able to tell us about identities, power politics, social geographies and counter-histories (e.g. Brackett 2000; Covach 1999; Frith 1996; Hawkins 2002; Moore 2003; Scott 2009; Shuker 2001). Although popular musicology and popular music sociology share much in common, there have been numerous contentions between a musicological vis-à-vis a cultural sociological approach. During the 1980s in particular, many scholars invested in the 'low' cultural values of pop and rock music forms charged orthodox musicology with a systemic lack of engagement with embodied and emotional music performance and reception. Furthermore, problematising orthodox musicology and its lingering resistance to critical theory in examinations of musical meaning and the broader social and cultural value of studying popular styles.

In his discussion of these disciplinary contentions, Shuker points to traditional musicological emphasis being placed on interpretation through score-based transcription, while popular music studies have tended to emphasise 'interpretation through performance', given that popular music 'is received primarily in terms of the body and emotions rather than as pure text' Shuker $(2001,140)$. While debates still loom regarding popular musicology's 'desire to understand popular music qua music' (Scott 2009, 21) and cultural sociologists focus on popular music's ability to leverage social action and collective identity, when speaking specifically in terms of queerness and popular music, multivocality of theory, scope and method - is increasingly understood as being of utmost importance. Since the 1990s, popular musicology has been more attentive to the phenomenological volatility of music reception and performance and since the mid 2000s in particular, we have seen a vibrant body of work on queerness and popular music emerge (e.g. Butler 2007; Currid 1995; Goldin-Perschbacher 2007; Halberstam 2007; Hawkins 2007, 2009; Jarman-Ivens 2009, 2011; Peraino 2006; Schwandt 2009; Whiteley and Rycenga 2006).

Twelve years after the publication of the ground-breaking anthology Queering the Pitch: The New Lesbian and Gay Musicology (Brett et al. 1994), Whiteley and Rycenga attempted to revisit and expand upon many of the themes of the original volume through an updated, edited collection focusing exclusively on popular music discourses. This was entitled Queering the Popular Pitch (2006). Unlike its predecessor, the very absence of a subtitle to this volume hinted at new imaginings for the potential of queering within the discipline and more accurately signalled queer's widening political critique. In the preface to this volume, Whiteley announced that the 2003 Biennial Conference of the International Association for the Study of Popular Music (IASPM) held in Montreal was the impetus behind this work. At the IASPM plenary on 'queering' in 2003, Rycenga (who was also a contributor to the original Queering the Pitch) spoke to the meaning of the term 'queer', highlighting the radical challenge queering poses to heteronormative representations of gender and sexuality. Other attendants cited their fears that queering was in danger of losing its radical edge if it continued to only be attentive to issues of white, 
middle-class lesbian and gay identity at the expense of other forms of queerness. By Whiteley's own admission, queering needed to be wrenched from the 'doldrums of generalized gender debates and to foreground current issues - not the least of which are those concerning ethnicity and class' (2006a, xi).

Extending the application of queer beyond the scope of white, middle-class gender and sexual identities, Queering the Popular Pitch attempted to provide music-centred accounts of queer scenes, subcultures and communities (e.g. Devitt 2006; Halberstam 2006; Oaks 2006; Tongson 2006), queer racial and ethnic identities (e.g. Callen 2006; Padva 2006; Ray 2006), queer representations of celebrity (e.g. Kerton 2006; Mayhew 2006), and queer interventions in popular music forms, discourses and power structures (e.g. Hawkins 2006; Rycenga 2006; Whiteley 2006b). As a collected whole, the book provides an understanding of queer gender and sexual identity that is, for the most part, cautious of the gender specificities signified and limited in the phrase 'lesbian and gay', highlighting how music provides a context for new examinations of, and ways to contemplate, a range of genders and non-heterosexualities. For example, in Devitt's (2006) discussion of queer femme queening, she illustrates how Def Leppard's "Pour Some Sugar on Me" is used to reclaim space for feminie sexuality within the masculine-centric world of drag kinging. With reference to Israeli pop star Eran Zur, Padav (2006) offers an examination of genderfuck and what he terms 'erotic flexibility' in the production of the 'queer musical statement' (2006, 111) that is Zur's album, You Are My Girlfriend. Through critical engagements with queer theoretical premises that attempt to unpack the monolith of homosexuality in ethnic contexts, new 'multidentities' also emerge - ones that engender a timely challenge to the flexibility of queer itself. In Amico's chapter on Latin house music, sexuality and place, he exercises scepticism towards commonly accepted (queer) notions of performativity and flexible subjectivities, noting: 'it is still important not to eschew the idea that, for many, the belief in a "stable" identity functions within their own discourses of self-presentation' (2006, 137). Building on this, Amico demonstrates how 'musical cross-fertilization' and 'music syncretization' emerge as a result of 'multidentitied musicians interacting with other forms and agents' $(2006,138)$. Ultimately, Amico argues that in order for queer work to maintain its radical edge, it does not always need to do away with the lived realities of fixed forms of self-presentation.

I point to these examples (of which there are others) because they signal the necessary interdisciplinary side-steps into areas such as theatre and literature studies, ethnography, racial and ethnic critique and countercultural histories that are crucial to achieving a more equitable and accurate understanding of queer popular musics. To effectively deal with popular music as an attendant realm of queerness and to understand the uniqueness and sophistication of queer socio-musical contexts, it is essential that we champion not only equitable but radical ways to situate interrogations of queer people, cultures, subcultures and the music that distinguishes them. As Lewis (2009) prefaces in her introduction to a special queer issue of Women and Music, it remains vital that queer music scholarship engages more broadly with critiques of race, ethnicity, class and nation, otherwise it is at great risk of propagating Western and possibly imperialist bias.

\section{Conclusion}

Queer subcultures and minority cultural production is vibrant and diverse and the narratives of queer culture-makers have, for far too long, been excluded from traditional accounts. Today, however, in line with an increase in queer urban subcultures, the study 
of queer subcultural identities and the concomitant production and consumption of popular music is a burgeoning area of research. In this article, I have argued that scholars who bring a queer perspective to subcultural and popular music research inevitably straddle disciplines and attended to some of the ways that queer identities, cultures and assemblages can problematise conventional subcultural frameworks. While the various theoretical perspectives, approaches and empirical literatures surveyed in this article underscore the robustness of queer studies as a multidisciplinary field of inquiry, there is still significant work to be done and numerous fertile plots of subcultural activity and cultural (especially musical) production that are yet to glean any significant scholarly attention. As queer work by the likes of du Plessis and Chapman (1997), Halberstam (2005), Whiteley and Rycenga (2006), Gržinić and Reitsamer (2008), and Lewis (2009) has argued, through recording and disseminating knowledge, institutions such as the academy reproduce the public sphere and if such institutions continue to ignore the efforts, narratives and products of queer subcultures we may be at risk of loosing vital queer cultural knowledge. Particularly, those forms of knowledge produced and consumed by queer women, queer people of colour, and in non-Western and non-Anglo contexts. Lastly, identifying the reasons why queer subcultures and cultural production 'need to be reckoned with on [their] own terms' (Halberstam 2005, 154), is an important part of progressing queer scholarship. As scholars, and particularly for those of us who identify with aspects of sexual minority culture, we must continue to contribute to the queer archive in ways that are attentive to the multiplicity of styles and cultural forms that manifest as unique expressions of sexual difference.

\section{Short Biography}

Jodie Taylor is currently a research fellow at the Queensl and Conservatorium Research Centre, Griffith University and previously held postdoctoral research fellowship at the Griffith Centre for Cultural Research. She is the author of Playing it Queer: Popular Music, Identity and Queer World-making (Peter Lang 2012) and co-editor of two forthcoming collections: The Festivalisation of Culture: Place, Identity and Politics (Ashgate 2012) and Redefining Mainstream Popular Music (Routledge 2012). She is also co-editor of a Special edition of Continuum on 'erotic screen and sound' (2012). Additionally, Jodie has authored numerous journal articles and book chapters on queer scenes, popular music and identity, and ethnographic methods.

\section{Notes}

* Correspondence address: Dr Jodie Taylor, Research Fellow, Queensland Conservatorium Research Centre, Griffith University, Street address: 140 Grey St, South Bank, Post: PO Box 3428, South Brisbane, Qld 4101, Australia. Email: jodie.taylor@griffith.edu.au

1 For a post-subcultural analysis of queer music cultures that discusses the usefulness and applicability of terms and theoretical frameworks see Taylor 2012a,b.

2 See Hodkinson (2005) for a detailed discussion of insider research practices within youth subcultural studies more broadly. Additionally, see Dahl (2010) and Taylor (2011) for a critique of this ethnographic approach that deals specifically with queer research contexts.

3 Halberstam's suggestions for a queer subcultural theory was first published in the International Journal of Cultural Studies in 2003. Since then, it has been revised and reprinted in her book, which I reference in the text, as well as in the volumes Queering the Popular Pitch (Whiteley and Rycenga 2006) and Queer Youth Cultures (Driver 2008). Beyond studies of popular music and subcultures, additional examples of queer scholarship that engage and expand upon this approach have generally focused on the queer archive (e.g. Davis 2009; Leung 2007). 
4 For a discussion of specifically gay and lesbian subcultures, see respectively Dean's (2009) work on gay men and barebacking and Stein's (1997) work on lesbian generations.

5 Homo A Go Go is a radical queer music and arts festival in North America (see http://www.homoagogo.com).

6 Beginning in London in 1998, Queeruption is an annual festival of music, arts and political activism held in dif-

ferent cities around the world each year (see http://www.queeruption.org).

\section{References}

Amico, S 2006. 'Su casa es mi casa: Latin house, sexuality place.' Pp. 131-151 in Queering the Popular Pitch, edited by S. Whiteley and J. Rycenga. New York: Routledge.

Becker, H. 1963. Outsiders: Studies in the Sociology of Deviance. New York: Free Press.

Becquer, M and J. Gatti. 1997 [1991]. 'Elements of Vogue.' Pp. 445-53 in The Subcultures Reader, edited by K. Gelder and S. Thornton. NY and London: Routledge.

Bennett, A. 2000. Popular Music and Youth Culture: Music. Identity and Place. Houndmills, UK: Macmillan Press.

Bennett, A. 2006. 'Punk's not Dead: The Continuing Significance of Punk Rock for an Older Generation of Fans.' Sociology 40(2): 219-35.

Bennett, A and P. Hodkinson (eds) 2012. Ageing and Youth Cultures: Music, Style and Identity. Oxford, UK: Berg.

Bennett, A and K. Kahn-Harris (eds) 2004. After Subculture: Critical Studies in Contemporary Youth Culture. Hampshire: Palgrave MacMillan.

Bennett, A. and R. A. Peterson (eds) (2004). Music Scenes: Local, Translocal, and Virtual. Nashville, TN: Vanderbilt University Press.

Berlant, L and M. Warner. 1998. 'Sex in Public.' Critical Inquiry 24(2): 547-66.

Boellstorff, T. 2007. 'Queer Studies in the House of Anthropology.' Annual Review of Anthropology 36: 17-35.

Bourdieu, P. 1993. The Field of Cultural Production: Essays an Art and Literature. Trans. Richard Nice et al. New York: Collumbia UP.

Brackett, D. 2000. Interpreting Popular Music. Berkeley, CA: University of California Press.

Brett, P., E. Wood and G. Thomas (eds) 1994. Queering the Pitch: The New Gay and Lesbian Musicology. New York: Routledge.

Butler, J. 1988. 'Performative Acts and Gender Construction: An Essay in Phenomenology and Feminist Criticism.' Theatre Journal 40(4): 519-31.

Butler, J. 1990. Gender Trouble: Feminism and the Subversion of Identity. London: Routledge.

Butler, J. 1993. Bodies That Matter: On the Discursive Limits of Sex. New York: Routledge.

Butler, M. J. 2007. " "Some of us can Only Live in Songs of Love and Trouble": Voice, Genre/Gender, and Sexuality in the Music of Stephin Merritt.' Pp. 235-59 in Oh boy! Masculinities and Popular Music, edited by F. Jarman-Ivens. New York: Routledge.

Callen, J. 2006. 'Gender Crossings: A Neglected History of African American Music.' Pp. 185-98 in Queering the Popular Pitch, edited by S. Whiteley and J. Rycenga. New York: Routledge.

Chambers, I. 1985. Urban Rhythms: Pop Music and Popular Culture. London: MacMillan.

Ciminelli, D. and K. Knox. 2005. Homocore: The Loud and Raucous Rise of Queer Rock. Los Angeles: Alyson Books.

Clarke, G. 1997 [1981]. 'Defending ski-Jumpers: A Critique of Theories of Youth sub-Cultures.' Pp. 175-80 in The Subcultures Reader, edited by K. Gelder and S. Thornton. London: Routledge.

Clarke, J. 1976. 'Style.' Pp. 175-91 in Resistance Through Rituals: Youth Subcultures in Post-war Britain, edited by S. Hall and T. Jefferson. London: Hutchinson.

Cohen, P. 1972. 'Subcultural Conflict and Working Class Community.' Pp. 5-51 in Working Papers in Cultural Studies. Birmingham, UK: Centre for Contemporary Cultural Studies, University of Birmingham.

Cohen, S. 1991. Rock Culture in Liverpool: Popular Music in the Making. Oxford: Clarendon Press.

Cooper, D. 1996. 'Queercore.' Pp. 292-6 in The Material Queer, edited by D. Mortan. Boulder, CO: Westview Press.

Corber, R and S. Valocchi. 2003. 'Introduction.' Pp. 1-17 in Queer Studies: An Interdisciplinary Reader, edited by R. Corber and S. Valocchi. Oxford, UK: Blackwell.

Covach, J. 1999. 'Popular Music, Unpopular Musicology.' Pp. 452-70 in Rethinking Music, edited by N. Cook and M. Everist. Oxford, UK: Oxford University Press.

Cressy, P. G. 1932. The Taxi-Dane Hall. New York: Greenwood Press.

Currid, B. 1995. 'We are Family': House Music and Queer Performativity.' Pp. 165-96 in Cruising the Performative: Interventions Into the Repression of Ethnicity, Nationality and Sexuality, edited by S. E. Case, P. Brett and S. Foster. Bloomington, IN: Indiana University Press.

Cvetkovich, A. 2003. An Archive of Feelings: Trauma, Sexuality, and Lesbian Public Cultures. Durham: Duke University Press.

Cvetkovich, A. 2007. 'Public Feeling.' South Atlantic Quarterly 106(3): 459-68. 
Dahl, U. 2010. 'Femme on Femme: Some Reflections on Collaborative Methods and Queer Femme-Inist Ethnography.' Pp. 143-66 in Queer Methods and Methodologies: Intersecting Queer Theories and Social Science Research, edited by K. A. Browne and C. Nash. London: Ashgate.

Davis, O. 2009. 'Guillaume Dustan's 'Autopornobiographe': Is There Room for Trash in the Queer Subcultural Archive?.' Pp. 59-76 in Alienation and Alterity: Otherness in Modern and Contemporary Francophone Contexts, edited by H. Vassallo and P. Cooke. Bern: Peter Lang.

Dean, T. 2009. Unlimited Intimacy: Reflections on the Subculture of Barebacking. Chicago, IL: University of Chicago Press.

DeChaine, D. R. 1997. 'Mapping Subversion: Queercore Music's Playful Discourse of Resistance.' Popular Music and Society 21(4): 7-37.

DeNora, T. 2000. Music in Everyday Life. Cambridge, UK: Cambridge University Press.

Devitt, R. 2006. 'Girl on Girl: Fat Femmes, Bio-Queens, and Redefining Drag.' Pp. 27-39 in Queering the Popular Pitch, edited by S. Whiteley and J. Rycenga. New York: Routledge.

Doty, A. 1993. Making Things Perfectly Queer: Interpreting Mass Culture. Minneapolis, MN: University of Minnesota Press.

Driver, S. 2007. Queer Girls and Popular Culture: Reading, Resisting, and Creating Media. New York: Peter Lang.

Driver, S. (ed.) 2008. Queer Youth Cultures. Albany, NY: Sunny Press.

Duggan, L. 2003. The Twilight of Equality?: Neoliberalism, Cultural Politics, and the Attack on Democracy. Boston, MA: Beacon Press.

Edwards, T. 1998. 'Queer Fears: Against the Cultural Turn.' Sexualities 1(4): 471-84.

Escoffier, J. 1990. 'Inside the Ivory Closet: The Challenges Facing Lesbian and gay Studies.' Out/Look: National Lesbian and Gay Quarterly 10: 40-8.

Fenster, M. 1993. 'Queer Punk Fanzines: Identity, Community, and the Articulation of Homosexuality and Hardcore.' Journal of Communication Inquiry 17(1): 73-94.

Foucault, M. 1979 [1976]. The History of Sexuality: Vol. 1. An Introduction. Trans R. Hurley. London: Allen Lane.

Frith, S. 1987. 'Towards and Aesthetic of Popular Music.' Pp. 133-49.in Music and Society: The Politics of Composition, Performance and Reception, edited by R. Leppert and S. McClary. Cambridge, UK: Cambridge University Press.

Frith, S. 1996. Performing Rites: On the Values of Popular Music. Oxford, UK: Oxford University Press.

Frith, S and McRobbie, A. 1990 [1978]. 'Rock and Sexuality.' Pp. 371-89 in On Record: Rock, Pop and the Written Word, edited by S. Frith and A. Goodwin. New York: Pantheon.

Fuchs, C. 1998. 'If I had a Dick: Queers, Punks, and Alternative Acts.' Pp. 101-20 in Mapping the Beat: Popular Music and Contemporary Theory, edited by T. Swiss, J. Sloop and A. Herman. Malden, MA: Blackwell.

Giddens, A. 1991. Modernity and Self Identity: Self and Society in the Late Modern Age. Cambridge: Polity.

Giffney, N. 2009. 'The 'q' Word.' Pp. 1-13 in The Ashgate Companion to Queer Theory, edited by N. Giffney and M. O'Rourke. Aldershot, UK: Ashgate.

Goldin-Perschbacher, S. 2007. ' 'Not Without You': 'Unbearable Intimacy' and Jeff Buckley's Transgender Vocality.' Pp. 213-333 in Oh boy! Masculinities and Popular Music, edited by F. Jarman-Ivens. New York: Routledge.

Gržinić, M. and R. Reitsamer (eds) 2008. New Feminisms: Worlds of Feminism, Queer and Networking Conditions. Wein: Löcker.

Halberstam, J 2003. 'What's that smell? Queer temporalities and subcultural lives.' International Journal of Cultural Studies 6(3): 313-33.

Halberstam, J. 2005. In a Queer Time and Place: Transgender Bodies, Subcultural Lives. New York: New York University Press.

Halberstam, J. 2006. 'What's that Smell? Queer Temporalities and Subcultural Lives.' Pp. 3-25 in Queering the Popular Pitch, edited by S. Whiteley and J. Rycenga. New York: Routledge.

Halberstam, J. 2007. 'What's that Smell? Queer Voices and Musical Genders.' Pp. $183-95$ in Oh boy! Masculinities and Popular Music, edited by F. Jarman-Ivens. New York: Routledge.

Hall, D. 2003. Queer Theories. Hampshire, UK: Palgrave Macmillian.

Hall, S. and T. Jefferson (eds) 1976. Resistance Through Rituals: Youth Subcultures in Post-war Britain. London: Hutchinson.

Halperin, D. 1995. Saint Foucault: Towards a Gay Hagiography. New York: Oxford University Press.

Hawkins, J. 2007. '[Un]Justified: Gensures of Straight-Talk in Justin Timberlake's Songs.' Pp. 197-212 in Oh boy! Masculinities and Popular Music, edited by F. Jarman-Ivens. New York: Routledge.

Hawkins, S. 2002. Settling the Pop Score: Pop Texts and Identity Politics. Aldershot: Ashgate.

Hawkins, S. 2006. 'On Male Queering in Mainstream pop.' Pp. 279-94 in Queering the Popular Pitch, edited by S. Whiteley and J. Rycenga. New York: Routledge.

Hawkins, S. 2009. The British Pop Dandy: Masculinity, Popular Music and Culture. Aldershot: Ashgate.

Hebdige, D. 1991 [1979]. Subculture: The Meaning of Style. London: Routledge.

Hodkinson, P. 2005. ' 'Insider Research' in the Study of Youth Cultures.' Journal of Youth Studies 8(2): 131-49. 
Hodkinson, P. 2011. 'Ageing in a Spectacular 'Youth Culture': Continuity, Change and Community Amongst Older Goths.' The British Journal of Sociology 62(2): 262-82.

Hodkinson, P and W. Deicke (eds) 2007. Youth Cultures: Scenes, Subcultures and Tribes. New York: Routledge.

Holland, S. 2004. Alternative Femininities: Body, Age and Identity. Oxford, UK: Berg.

Huq, R. 2006. Beyond Subculture: Pop, Youth and Identity in a Postcolonial World. Oxon, UK: Routledge.

Jagose, A. 1996. Queer Theory. Melbourne, Vic: Melbourne University Press.

Jarman-Ivens, F. 2009. 'Notes on Musical Camp.' Pp.189-203 in The Ashgate Research Companion to Popular Musicology, edited by D. B. Scott. Aldershot: Ashgate.

Jarman-Ivens, F. 2011. Queer Voices: Technologies, Vocalities, and the Musical Flaw. Basingstoke: Palgrave Macmillan.

Jeffreys, S. 2003. Unpacking Queer Politics: A Lesbian Feminist Perspective. Cambridge: Polity Press.

Kearney, M. C. 1997. 'The Missing Link: Riot Grrrl, Feminism, Lesbian Culture.' Pp. 207-29 in Sexing the Groove: Popular Music and Gender, edited by S. Whiteley. London: Routledge.

Kerton, S. 2006. 'Too Much, Tatu Young: Queering Politics in the World of Tatu.' Pp. 155-68 in Queering the Popular Pitch, edited by S. Whiteley and J. Rycenga. New York: Routledge.

Laing, D. 1985. One Chord Wonders: Power and Meaning in Punk Rock. Milton Keynes, UK: Open University Press. Laughey, D. 2006. Music and Youth Culture. Edinburgh: Edinburgh University Press.

de Lauretis, T. 1991. 'Queer Theory: Lesbian and gay Sexualities. An Introduction.' Differences 3(2): iii-xviii.

Leung, H. 2007. 'Archiving Queer Feelings in Hong Kong.' Inter-Asia Cultural Studies 8(4): 559-71.

Lewis, R. 2009. 'What's Queer About Musicology Now.' Women and Music 13: 43-53.

Livingston, J. 1990. Paris is Burning [Film]. New York: Insight Media.

Martin, F., P. A. Jackson, M. McLennand and A. Yue (eds) 2008. AsiaPacifiQueer: Rethinking Genders and Sexualities. Urbana and Chicago: University of Illinois Press.

Mayhew, E. 2006. 'II am not in a box of any Description': Sinéad O'Connor's Queer Outing.' Pp. 169-84 in Queering the Popular Pitch, edited by S. Whiteley and J. Rycenga. New York: Routledge.

McClary, S. 1991. Feminine Endings: Music, Gender and Sexuality. Minneapolis, MN: University of Minnesota Press.

McRobbie, A. 1994. Postmodernism and Popular Culture. London: Routledge.

Meyer, M. 1994. 'Introduction.' Pp. 1-22 in The Politics and Poetics of Camp, edited by M. Meyer. London: Routledge.

Moore, A. (ed.) 2003. Analyzing Popular Music. Cambridge, UK: Cambridge University Press.

Muggleton, D. and R. Weinzierl (eds) 2003. The Post-Subcultures Reader. Oxford: Berg.

Muñoz, J. E. 1999. Disidentifications: Queers of Colour and the Performance of Politics. Minneapolis, MN: University of Minnesota Press.

Oaks, J. L. 2006. 'Queering the witch: Stevie Nicks and the forging of femininity at the night of a thousand Stevies.' Pp. 41-54 in Queering the Popular Pitch, edited by S. Whiteley and J. Rycenga. New York: Routledge.

Padva, G 2006. 'Hey, man, you're my girlfriend! Poetic genderfuck and queer Hebrew in Eran Zur's performance of Yona Wallach's lrics.' Pp. 101-114 in Queering the Popular Pitch, edited by S. Whiteley and J. Rycenga. New York: Routledge.

Peraino, J. A. 2006. Listening to the Sirens: Music Technologies of Queer Identity From Homer to Hedwig. Berkeley, CA: University of California Press.

Peters, B. M. 2010. 'Emo gay Boys and Subculture: Postpunk Queer Youth and (re)Thinking Images of Masculinity.' Journal of LGBT Youth 7(2): 129-46.

Phelan, S. 1997. 'Introduction.' Pp. 1-8 in Playing With Fire, Queer Politics, Queer Theories, edited by S. Phelan. New York: Routledge.

Phoenix, V. 1994. 'From Womyn to Grrrls: Finding Sisterhood in Girl Style Revolution.' Deneuve JanuaryFebruary: 40-3.

du Plessis, M. and K. Chapman. 1997. 'Queercore: The Distinct Identities of Subculture.' College Literature 24(1): 45-58.

Plummer, K. 1998. 'Afterward: The Past, Present and Futures of the Sociology of Same-sex Relations.' Pp. 605-14 in Social Perspectives in Lesbian and Gay Studies, edited by P. M. Nardi and B. E. Schneider. London: Routledge.

Ray, M. 2006. 'Albita Rodríguez: Sexuality, Imaging, and Gender Construction in the Music of Exile.' Pp. 115-30 in Queering the Popular Pitch, edited by S. Whiteley and J. Rycenga. New York: Routledge.

Redhead, S., D. Wynne and J. O'Connor (eds) 1997. The Clubcultures Reader: Readings in Popular Cultural Studies. Oxford: Blackwell.

Richardson, D., J. McLaughlin and M. E. Casey (eds) 2006. Intersections Between Feminist and Queer Theory. New York: Palgrave Macmillan.

Rycenga, J. 2006. 'Endless Caresses: Queer Exuberance in Large-Scale Form Rock.' Pp. 235-48 in Queering the Popular Pitch, edited by S. Whiteley and J. Rycenga. New York: Routledge.

Schwandt, K. 2009. 'The Erotics of an oil Drum: Queercore, gay Macho, and the Defiant Sexuality of Extra Fancy's Sinnerman.' Women and Music 13: 76-87.

Scott, D. B. (ed.) 2009. The Ashgate Research Companion to Popular Musicology. Surrey, UK: Ashgate.

Sedgwick, E. K. 1993. Tendencies. Durham, NC: Duke University Press.

Shank, B. 1994. Dissonant Identities: The Rock ' $n$ ' Roll Scene in Austin. Texas, London: Wesleyan University Press. 
Shoemaker, D. 2010. 'Queer punk macha femme: Leslie Mah's Musical performance in tribe 8.' Critical Studies, Critical Methodologies 10(4): 295-306.

Shuker, R. 2001. Understanding Popular Music. 2nd edition. London: Routledge.

Smith, N. 2009. 'Beyond the Master Narrative of Youth: Researching Ageing Popular Music Scenes.' Pp. 427-45 in The Ashgate Companion to Popular Musicology, edited by D. B. Scott. Surrey, UK: Ashgate.

Smith, R. 1995. 'Seduced and Abandoned: Essays on Gay Men and Popular Music. London: Casell.

Spencer, A. 2005. DIY: The Rise of Lo-fi Culture. London: Marion Boyars.

Stein, A. 1997. Sex and Sensibility: Stories of a Lesbian Generation. Berkeley, CA: University of California Press.

Stryker, S. 2006. '(De)Subjugated Knowledges: An Introduction to Transgender Studies.' Pp. 1-17 in The Transgender Studies Reader, edited by S. Stryker and S. Whittle. London: Routledge.

Sullivan, N. 2003. A Critical Introduction to Queer Theory. Armidale, Vic.: Circa.

Taylor, J. 2010a. 'Queer Temporalities: The Significance of 'Music Scene' Participation in the Social Identities of Middle-Aged Queers.' Sociology 44(5): 893-907.

Taylor, J. 2011. 'The Intimate Insider: Negotiating the Ethics of Friendship When Doing Insider Research.' Qualitative Research 11(1): 3-22

Taylor, J. 2012a. 'Scenes and Sexualities: Queerly Reframing the Music Scenes Perspective.' Continuum: Journal of Media \& Cultural Studies 26(1): 143-56.

Taylor, J. 2012b. Playing it Queer: Popular Music, Identity and Queer World-Making. Bern: Peter Lang.

Taylor, Y. 2010b. 'The "Outness" of Queer: Class and Sexual Intersections.' Pp. 69-84 in Queer Methods and Methodologies: Intersecting Queer Theories and Social Science Research, edited by K. A. Browne and C. Nash. Aldershot: Ashgate.

Thornton, S. 1995. Club Cultures: Music, Media and Subcultural Capital. Oxford, UK: Polity Press.

Tongson, K. 2006. 'Tickle Me Emo: Lesbian Balladeering, Straight-Boy Emo, and the Politics of Affect.' Pp. 5566 in Queering the Popular Pitch, edited by S. Whiteley and J. Rycenga. New York: Routledge.

Valdivia, A. N. 2003. 'Racial Hybridity: Latinas/os as the Paradigmatic Transnational Post-Subculture.' Pp. 151-65 in The Post-Subcultures Reader, edited by D. Muggleton and R. Weinzierl. Oxford: Berg.

Warner, M. 1999. The Trouble with Normal: Sex, Politics, and the Ethics of Queer Life. New York: The Free Press.

Warner, M. (ed.) 1993. Fear of a Queer Planet: Queer Politics and Social Theory. Minneapolis, MN: University of Minnesota Press.

Weeks, J. 2000. 'The Challenge of Lesbian and gay Studies.' Pp. 1-13 in Lesbian and Gay Studies: An Introductory, Interdisciplinary Approach, edited by T. Sandfort, J. Schuyf, J. W. Duyvendak and J. Weeks. London: Sage.

Whiteley, S. 2006a. 'Preface.' Pp. xi-xii in Queering the Popular Pitch, edited by S. Whiteley and J. Rycenga. New York: Routledge.

Whiteley, S. 2006b. 'Popular Music and the Dynamics of Desire. Pp.' 249-62 in Queering the Popular Pitch, edited by S. Whiteley and J. Rycenga. New York: Routledge.

Whiteley, S and J. Rycenga. 2006. 'Introduction.' Pp. xiii-Xix In Queering the Popular Pitch, edited by S. Whiteley and J. Rycenga. New York: Routledge.

Whyte, W. F. 1943. Street Corner Society: The Social Structure of an Italian Slum. Chicago: Chicago University Press.

Wiedlack, M. K. 2011. ' 'LOL - Lick it out Loud:' Punk Rock as a Form of Queer Activism.' Pp. 209-24 in Queering Paradigms II: Interrogating Agendas, edited by B. Scherer and M. Ball. Bern: Peter Lang.

Williams, J. P. 2007. 'Youth-Subcultural Studies: Sociological Traditions and Core Concepts.' Sociology Compass 1(2): 572-93.

Willis, P. 1978. Profane Culture. London: Routledge and Kegan Paul.

Wilson, A. 2008. "The Galaxy is Gay". Examining the Networks of Lesbian Punk Rock Subculture.' Pp. 51-68 in Queer Youth Cultures, edited by S. Driver. Albany, NY: Sunny Press.

Wilson, D. M. 2007. 'Post-Pomo hip-hop Homos: Hip-hop art, gay Rappers, and Social Change.' Social Justice 34(1): $117-40$ 